\title{
EIF3B wt Allele
}

National Cancer Institute

\section{Source}

National Cancer Institute. ElF3B wt Allele. NCI Thesaurus. Code C96375.

Human EIF3B wild-type allele is located in the vicinity of 7 p22.3 and is approximately 25 $\mathrm{kb}$ in length. This allele, which encodes eukaryotic translation initiation factor 3 subunit $B$ protein, is involved in the regulation of translation. 